\title{
Th17 cell-derived IL-17 is dispensable for B cell antibody production
}

Akiko Shibui $^{\mathrm{a}}$, Eri Shimura ${ }^{\mathrm{b}}$, Aya Nambu $^{\mathrm{c}}$, Sachiko Yamaguchi ${ }^{\mathrm{e}}$, Warren J. Leonard ${ }^{\mathrm{d}}$, Ko

Okumura $^{\mathrm{b}}$, Sumio Sugano ${ }^{\text {a }}$, Katsuko Sudo ${ }^{\mathrm{e}}$, Susumu Nakae ${ }^{\mathrm{c}, \mathrm{e}, \mathrm{f}, \mathrm{g}^{*}}$

${ }^{a}$ Department of Medical Genomics, Graduate School of Frontier Sciences, The University of Tokyo, Chiba 277-8561, Japan

${ }^{\mathrm{b}}$ Atopy Research Center, Juntendo University, Tokyo, 113-8412, Japan

${ }^{c}$ Laboratory of Systems Biology, Center for Experimental Medicine and Systems Biology and ${ }^{\mathrm{e}}$ Frontier Research Initiative, The Institute of Medical Science, The University of Tokyo, Tokyo, 108-8639, Japan

d Laboratory of Molecular Immunology, National Heart, Lung, and Blood Institute, National Institutes of Health, Bethesda, MD 20892

e Animal Research Center, Tokyo Medical University, Tokyo 160-8402, Japan

${ }^{\mathrm{f}}$ Precursory Research for Embryonic Science and Technology (PRESTO), Japan Science and Technology Agency, Saitama 332-0012, Japan

*Address correspondence to:

Susumu Nakae, Ph.D.

Frontier Research Initiative

Laboratory of Systems Biology, Center for Experimental Medicine and Systems Biology The Institute of Medical Science

The University of Tokyo

4-6-1 Shirokanedai, Minato-ku, Tokyo, 108-8639, Japan

Tel: +81-3-6409-2111, Fax: +81-3-6409-2109

E-mail: snakae@ims.u-tokyo.ac.jp 


\begin{abstract}
IL-17, which is preferentially produced by Th17 cells, is important for host defense against pathogens and is also involved in the development of autoimmune and allergic disorders. Antibody $(\mathrm{Ab})$ production was shown to be impaired in IL-17-deficient mice, suggesting that IL-17 may promote B cell activation and direct secretion of Ab. However, the precise role of IL-17 in Ab production by B cells remains unclear. In the present study, we found constitutive expression of IL-17R in murine splenic B cells. Nevertheless, IL-17, IL-17F or IL-25 alone could not induce Ab production by B cells even in the presence of agonistic anti-CD40 Ab. IL-17 also could not affect IFN- $\gamma-$, IL-4- or TGF- $\beta 1$-mediated Ig class-switching. Furthermore, in cocultures of B cells and IL-17 $\mathrm{CD}^{+}$T cells or IL-17 ${ }^{-/-}$Th17 cells, IL-17 deficiency did not influence Ab production by $\mathrm{B}$ cells in vitro, suggesting that Th17 cell-derived IL-17 was not required for B cell Ab production through T-B cell interaction in vitro. Thus, in vivo, IL-17 may be indirectly involved in $\mathrm{Ab}$ production by enhancing production of $\mathrm{B}$ cell activator(s) by other immune cells.
\end{abstract}


Key words: interleukin-17, Th17 cells, B cells, antibody production

Abbreviations: IL, interleukin; Th, T helper type; IL-17R, interleukin-17 receptor; CD, cluster of differentiation; IFN- $\gamma$, interferon- $\gamma$; Ig, immunoglobulin; STAT-6, signal transducer and activator of transcription- 6 ; TGF- $\beta$, tumor growth factor- $\beta$; BSA, bovine serum albumin; LPS, lipopolysaccharide; BAFF, B cell-activating factor belonging to the TNF family; PNA, peanut agglutinin; RT-PCR, reverse transcriptase-polymerase chain reaction; ELISA, enzyme-linked immunosorbent assay; TCR, T-cell receptor.

\section{Introduction}

It is well known that $\mathrm{T}$ cell-derived cytokines are involved in Ig class-switch recombination in $\mathrm{B}$ cells, contributing to the development of Ab-dependent diseases [1]. IFN- $\gamma$, a Th1-type cytokine, enhances the Ig class-switch recombination for IgG2a and IgG3 [2], while IL-4, a Th2-type cytokine, promotes it for IgG1 and IgE by activation of STAT-6, which binds to $\mathrm{C} \gamma 1$ and $\mathrm{C} \varepsilon 1$ germline promoters [3]. TGF- $\beta$ is known to regulate $\operatorname{IgG} 2 \mathrm{~b}$ and $\operatorname{IgA}$ production by B cells $[4,5]$.

IL-17, which is preferentially produced by Th17 cells, is important for host defense against various pathogens, while inappropriate/excessive production of IL-17 by Th17 cells is considered to be involved in the development of certain autoimmune and allergic disorders [6]. Antigen-specific Ig production was significantly decreased in IL-17-deficient (IL-17 ${ }^{-/}$) mice during allergic diseases such as trinitrochlorobenzene-induced contact hypersensitivity, methylated BSA-induced 
delayed-type hypersensitivity and ovalbumin (OVA)-induced airway inflammation [7], and autoimmune diseases such as collagen-induced arthritis [8], suggesting involvement of IL-17 in Ig class-switch recombination in B cells. Although proliferation and Ab production by $\mathrm{B}$ cells from IL-17/- mice were normally observed after anti-IgM Ab and LPS stimulation in vitro [7], IL-17 together with BAFF, but not IL-17 alone, can enhance survival, proliferation and Ig class switching in B cells via transcription factor Twist1 activation in vitro [9]. Germinal center formation was impaired in IL-17RA ${ }^{-/-}$mice [10, 11], whereas it was normal in IL-17/- mice [8], suggesting involvement of IL-17F and IL-25, which are ligands for IL-17RA, in the event. In addition, it was recently reported that Th17 cell-derived IL-21 is very important for Ig class-switch recombination in B cells and formation of germinal centers in mouse spleen, rather than Th17 cell-derived IL-17 [11]. Therefore, the precise role of IL-17 derived from Th17 cells in Ig class-switch recombination in B cells has been unclear. In the present study, we further investigated that role using IL-17-deficient Th17 cells. 


\section{Materials and Methods}

\subsection{Reagents}

The following reagents were purchased from BioLegend (San Diego, CA), eBioscience (San Diego, CA) or BD Biosciences (San Diego, CA): unlabeled anti-mouse CD16/32 (93), CD40 (3/23), IFN- $\gamma$ (XMG1.2) and IL-4 (11B11) mAbs, biotin-conjugated anti-mouse CD8 $\alpha$ (53-6.7), CD11c (N418), CD25 (PC61.5), CD45R/B220 (RA3-6B2),

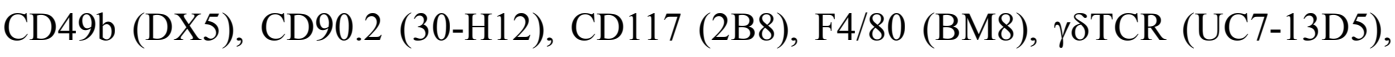
Ly-6G (RB6-8C5) and TER-119 (TER-119) mAbs, PE-conjugated anti-mouse Fas (I5A7) mAb, and APC-conjugated anti-mouse B220 (RA3-6B2) mAb. Recombinant mouse IFN- $\gamma$, IL-1 $\beta$, IL-4, IL-6 and TNF, recombinant human TGF- $\beta 1$, and recombinant mouse IL-17, IL-17F, IL-23 and IL-25 were obtained from PeproTech (Rocky Hill, NJ) and R\&D Systems (Minneapolis, MN), respectively.

\subsection{Mice}

Wild-type BALB/cCr and C57BL/6J mice were purchased from Japan SLC (Hamamatsu, Japan). OTII mice were obtained from Taconic Farms (Germantown, NY). $\mathrm{C} 57 \mathrm{BL} / 6-\mathrm{IL}-17^{-/-}$and $-\mathrm{IL}-21 \mathrm{R}^{-/-}$mice were generated as described elsewhere $[7,12]$.

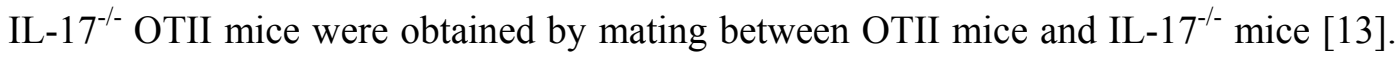
The mice were housed under specific pathogen-free conditions at The University of Tokyo and Tokyo Medical University, and the animal protocols were approved by the Institutional Review Board of each institution. 


\subsection{Flow cytometry}

C57BL/6-wild-type and IL-17/- mice were immunized intraperitoneally with $200 \mu \mathrm{l}$ of 500- $\mu \mathrm{g} / \mathrm{ml}$ OVA (grade V, Sigma-Aldrich, St. Louis, MO) emulsified with alum (Imject Alum $^{\circledR}$, Pierce, Rockford, IL) on days 0 and 7. On day 14, spleens were harvested, and spleen cells were incubated with FITC-conjugated peanut agglutinin (PNA) (Sigma-Aldrich), PE-anti Fas mAb and APC-anti B220 mAb on ice after FcR blocking by addition of anti-CD16/CD32 mAb. The proportion of $\mathrm{PNA}^{+} \mathrm{Fas}^{+}$cells in 7-aminoactinomycin C-negative $\mathrm{B} 220^{+}$cells was analyzed on a FACSCalibur flow cytometer (Becton Dickinson, Franklin Lakes, NJ) using CellQuest software (Becton Dickinson).

\subsection{Preparation of $B$ and $T$ cells}

B cells $\left(B 220^{+}\right.$cells $\left.>95 \%\right)$ or $\mathrm{CD}^{+} \mathrm{T}$ cells $\left(\mathrm{CD} 4^{+}\right.$cells $\left.>95 \%\right)$ were isolated from spleen cells by negative selection using BD IMag ${ }^{\mathrm{TM}}$ Streptavidin Particles Plus-DM (BD Bioscience, San Jose, CA) according to the manufacturer's instructions after incubation with biotin-conjugated anti-mouse CD11c, CD49b, CD117, $\gamma \delta T C R, F 4 / 80$, Ly-6G and TER119 plus biotin-conjugated anti-mouse CD90.2 (for B cells) or anti-mouse B220 (for $\mathrm{CD} 4^{+} \mathrm{T}$ cells $)$.

\subsection{RT-PCR}

Total RNA was extracted from B cells using TRIzol® Reagent (Invitrogen Life Technologies, Carlsbad, CA). Then, cDNA was prepared using a Prime Script ${ }^{\circledR}$ RT 
reagent kit (TaKaRa Bio, Shiga, Japan). For RT-PCR, GoTaq ${ }^{\circledR}$ DNA Polymerase (Promega, Madison, WI) was used according to the manufacturer's protocol. The PCR conditions were: $\left(94^{\circ} \mathrm{C}\right.$ for $40 \mathrm{sec} \rightarrow 54{ }^{\circ} \mathrm{C}$ for $30 \mathrm{sec} \rightarrow 72{ }^{\circ} \mathrm{C}$ for $1 \mathrm{~min}$ ) x 35 cycles for IL-17RA and $\beta$-actin expression, and $\left(94^{\circ} \mathrm{C}\right.$ for $40 \mathrm{sec} \rightarrow 54^{\circ} \mathrm{C}$ for $30 \mathrm{sec} \rightarrow 72{ }^{\circ} \mathrm{C}$ for 30 sec) x 38 cycles for IL-17RC expression. The following primers were used:

5'-ATCTGTATGACCTGGAGGCTTTCT-3' and

5'-GAGTAGACGATCCAGACCTTCCT-3' for IL-17RA;

5'-CGATCACACCAGTGTATGCAG-3' and

5'-TAGAAGGAGGAAGAAGAAAAGCG-3' for IL-17RC; and

5'-ATGGATGACGATATCGCTGCG-3' and 5'-GGGCACAGTGTGGGTGACCCC-3' for $\beta$-actin.

The band sizes of the fragments were $156 \mathrm{bp}$ (IL-17RA), $172 \mathrm{bp}$ (IL-17RC) and $491 \mathrm{bp}$ ( $\beta$-actin).

\subsection{Generation of Th17 cells}

Spleen cells $\left(2 \times 10^{6}\right.$ cells $\left./ \mathrm{ml}\right)$ from OTII mice and IL-17 $7^{-/-}$OTII mice were suspended in RPMI 1640 medium supplemented with 10\% FBS and $50 \mu \mathrm{M}$ 2-mercaptoethanol and cultured in the presence of $0.1 \mu \mathrm{M}_{\text {OVA }}$ O23-339 peptides with $5 \mathrm{ng} / \mathrm{ml} \mathrm{rhTGF}-\beta 1,20 \mathrm{ng} / \mathrm{ml}$ rmIL-6, $10 \mathrm{ng} / \mathrm{ml} \mathrm{rmIL-1 \beta ,} 10 \mathrm{ng} / \mathrm{ml} \mathrm{rmIL-23,} 10 \mathrm{ng} / \mathrm{ml} \mathrm{rmTNF}, 10 \mu \mathrm{g} / \mathrm{ml}$ anti-mouse IL-4 $\mathrm{mAb}$ and $10 \mu \mathrm{g} / \mathrm{ml}$ anti-mouse IFN- $\gamma \mathrm{mAb}$ at $37^{\circ} \mathrm{C}$ for 5 days. Then $\mathrm{CD}^{+} \mathrm{T}$ cells were isolated as described above. IL- $17^{+}$Th17 cells were approximately $20-25 \%$ in CD $4^{+}$ T cells by FACS analysis. 


\subsection{Cell culture}

Splenic B cells $\left(1 \times 10^{5}\right.$ cells/well in a 96-well flat-bottom plate $)$ from BALB/c mice were stimulated with $3 \mu \mathrm{g} / \mathrm{ml}$ anti-mouse CD40 mAb with and without $10 \mathrm{ng} / \mathrm{ml} \mathrm{rmIFN-} \gamma, 10$ $\mathrm{ng} / \mathrm{ml} \mathrm{rmIL-4}$ or $0.1 \mathrm{ng} / \mathrm{ml} \mathrm{rhTGF}-\beta 1$ in the presence of various concentrations of rmIL-17 or $100 \mathrm{ng} / \mathrm{ml} \mathrm{rmIL-17,} \mathrm{rmIL-17F} \mathrm{and} \mathrm{rmIL-25} \mathrm{at} 37^{\circ} \mathrm{C}$ for 6 days. Splenic B cells $\left(1 \times 10^{5}\right.$ cells/well in a 96-well flat-bottom plate) from C57BL/6J-wild-type or -IL-21 $\mathrm{R}^{-/-}$mice were cocultured with irradiated $\mathrm{CD} 4^{+} \mathrm{T}$ cells $\left(2 \times 10^{5}\right.$ cells/well $)$ in the presence and absence of $0.1 \mu \mathrm{M} \mathrm{OVA}_{323-339}$ peptides at $37^{\circ} \mathrm{C}$ for 6 or 7 days. Then the culture supernatants were collected for ELISA.

\subsection{ELISA}

The levels of IgA, IgE, IgG1, IgG2a, IgG2b, IgG2c and IgG3 in culture supernatants were determined with ELISA Quantitation Kits (Bethyl Laboratories, Montgomery, TX) according to the manufacturer's instructions.

\subsection{Statistical analysis}

Data show the mean with SEM and were evaluated for statistical significance using the two-tailed Student's $t$ test. 


\section{Results}

\subsection{Effects of IL-17 on Ab production by $B$ cells in vitro}

We previously demonstrated that antigen-specific Ig production was impaired, but germinal center formation was normal, in IL-17 $7^{-/-}$mice with collagen-induced arthritis [8]. Consistent with this, OVA-specific Ig production was impaired in IL-17 $7^{-/}$ mice (data not shown), as shown previously [7], when mice were immunized with OVA emulsified with alum. However, the proportion of $\mathrm{B} 220^{+} \mathrm{PNA}^{+} \mathrm{Fas}^{+}$germinal center B cells from the spleen were similar between IL-1 $7^{-/-}$and wild-type mice after immunization with alum-emulsified OVA (Fig. 1A, B). These observations suggest that IL-17 may contribute to Ig production by B cells, but not the development of germinal center B cells. To investigate IL-17 for a direct effect, we first examined IL-17R expression in B cells by RT-PCR. As shown previously [10], constitutive expression of IL-17RA and IL-17RC was seen in B cells isolated from the spleen of BALB/c mice (Fig. 2). However, the expression of IL-17RA and IL-17RC on the cell surface of B cells was barely detectable by FACS analysis (data not shown). Next, B cells isolated from the spleen of BALB/c mice were cultured with various concentrations of rmIL-17 in the presence and absence of anti-CD40 $\mathrm{mAb}$, and the Ig levels in the culture supernatants were determined by ELISA. As shown in Fig. 3, IL-17 had no effect on the production of any Ig class/subclass by B cells. When B cells were stimulated with anti-CD40 mAb, only a high concentration of IL-17 (100 ng/ml) enhanced IgG2b and IgG2c production, but not other Ig class/subclass production. IL-17R expression was not affected in that system (data not shown). These observations suggest that IL-17 plays no role, directly or 
indirectly, in Ig production by B cells via CD40 signals.

We next examined IL-17 for effects on IFN- $\gamma$-mediated IgG2a and IgG3

production [2], IL-4-mediated IgE and IgG1 production [3] and TGF- $\beta 1$-mediated IgA and $\operatorname{IgG} 2 \mathrm{~b}$ production $[4,5]$. Purified splenic B cells were cultured with rmIFN- $\gamma$, rmIL-4 or rhTGF- $\beta 1$ in the presence and absence of anti-CD40 mAb, with various concentrations of rmIL-17 (Fig. 4). IL-17 had no effects on Ig production in these settings (Fig. 4), indicating that it makes little or no contribution, directly or indirectly, to Ig class-switching and Ig production by B cells via CD40-mediated signals.

\subsection{Role of Th17 cell-derived IL-17 in Ig production by B cells in vitro}

It was recently shown that IL-17, together with BAFF, but not alone, can enhance survival, proliferation and Ig class-switching in B cells in vitro [9]. That suggested that IL-17 may be important for Ig class-switching and production by B cells through B cell-T cell interaction via co-stimulatory molecules such as BAFF, but not CD40 (as shown above). To elucidate this, purified splenic B cells were cocultured with OVA-specific TCR-expressing CD4 ${ }^{+} \mathrm{T}$ cells from wild-type or IL- $17^{-/-}$mice on the OTII-transgenic background in the presence and absence of OVA peptides. In the setting, the levels of IgA, IgE and IgG subclasses in the culture supernatants were comparable between the groups (Fig. 5). Likewise, the levels of IgA, IgE and IgG subclasses were equivalent in the culture supernatants of B cells cocultured with Th17 cells derived from either IL-17 $7^{-/}$ OTII mice or wild-type OTII mice (Fig. 6). These observations indicate that IL-17 derived from $\mathrm{CD}^{+} \mathrm{T}$ cells, including Th17 cells, is not required for Ig class-switching 
and production by B cells through B cell-T cell interaction.

\subsection{Effects of IL-17F, IL-21 and IL-25 on Ab production by $B$ cells in vitro}

Mice deficient in IL-17RA, which is a common component of receptors for

IL-17, IL-17F and IL-25 [6], showed the impaired germinal center formation and (auto)antibody production [10], suggesting that IL-17F and/or IL-25 rather than IL-17 may contribute to the setting. Although B cells isolated from the spleen of BALB/cCr mice were cultured with rmIL-17F and rm IL-25 as well as rmIL-17 in the presence and absence of anti-CD40 mAb, both IL-17F and IL-25 had no effect on the production of any Ig class/subclass by B cells (Fig. 7).

Recently, it has been shown that Th17 cell-derived IL-21 is involved in Ig production in vitro [11]. To elucidate the role of IL-21 produced by Th17 cells in Ig production, purified splenic B cells from wild-type and IL-21 $\mathrm{R}^{-/-}$mice were cocultured with Th17 cells derived from OTII mice in the presence and absence of OVA peptides. In the setting, the levels of IgG3 were decreased, but those of IgG2b were increased, in the culture supernatants from IL-21R $\mathrm{R}^{-/-} \mathrm{B}$ cells compared with that from wild-type B cells (Fig. 8). The levels of $\operatorname{IgA}$, IgE, IgG1 and IgG2c in the culture supernatants were comparable between the groups (Fig. 8). These observations suggest that Th17 cell-derived IL-21 contributes to but is not essential for Ig production and class switching at least in vitro. 


\section{Discussion}

IL-17 is considered to be an important cytokine for Ig production by B cells, since antigen-specific Ig production was reduced in $\mathrm{IL}-17^{-/-}$mice $[7,8]$ and increased in IL-17-overexpressing mice [10]. However, the precise roles of IL-17 (particularly IL-17 derived from Th17 cells) in Ig production by B cells remain unclear.

We previously demonstrated that antigen-specific Ig production was impaired, but germinal center formation was normal, in IL-1 $17^{-/-}$mice with collagen-induced arthritis [8] or IL-17 $7^{-/-}, \mathrm{IL}-17 \mathrm{~F}^{-/-}$and ROR- $\alpha / \gamma^{-/-}$mice after immunization with keyhole limpet hemocyanin [14]. On the other hand, germinal center formation and (auto)antibody production were impaired in IL-17RA ${ }^{-/-}$mice on a BXD2 mouse background [10] and IL-17RA ${ }^{-/-}$mice injected with myelin oligodendrocyte glycoprotein-specific Th17 cells [11]. Since IL-17RA is a common component of receptors for IL-17, IL-17F and IL-25 [6], the phenotypic differences between IL-17 $7^{-/}$ and IL-17RA ${ }^{-/-}$mice may be affected by IL-17F derived from Th17 cells. Indeed, like IL-17 $7^{-/-}$mice, IL-17F ${ }^{-/-}$mice showed reduced Ig production in certain immune responses [15], although the contribution of IL-17F to Ig production was less than that of IL-17 in studies of IL-17 $7^{-/-}$and IL-17F ${ }^{-/-}$mouse responses $[15,16]$. However, like IL-17, IL-17F and IL-25 were not essential for the production of any Ig class/subclass by B cells in the presence or absence of anti-CD40 agonistic $\mathrm{Ab}$ in vitro.

Recently, Mitsdoerffer et al. reported that in vitro skewed Th17 cells enhanced Ig production and proliferation of B cells in vitro [11]. Particularly, Th17 cell-derived IL-17 or IL-21 is important for the responses [11]. However, we observed normal Ig production

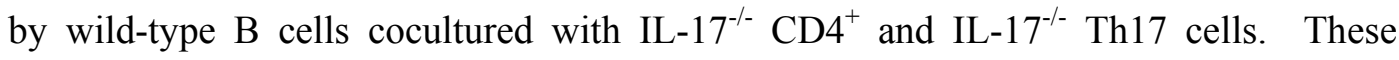


observations suggest that Th17 cell-derived cytokines such as IL-17F and IL-21 may be important for Ig production. Although IL-21 is known to be crucial for Ig class-switching and production in vivo [12], we found that Th17 cell-derived IL-21 partially, but not crucially, contributed to the responses in vitro. As reported elsewhere [14], follicular helper T cell-, rather than Th17 cell-, derived IL-21 may be crucial for the events. Supportively, we observed the reduced IgG1 production in the culture supernatants from IL-21 $\mathrm{R}^{-/-} \mathrm{B}$ cells cocultured with IL-6/IL-21-induced OTII follicular helper T cells in the presence of OVA peptides (unpublished observations).

In our present study, IL-17 did not induce IgE production by mouse B cells in vitro, whereas IL-17 promoted IgE class-switching and Ig production by human B cells in vitro [17]. On the other hand, recently, mutation of STAT3, which is required for IL-6, IL-21, IL-22 and IL-23 signaling, resulted in development of hyper IgE syndrome [18] and impaired Th17 cell differentiation [19]. Those results suggested that Th17 cells and Th17 cell-derived cytokines, including IL-17, IL-17F and IL-21, may not be essential for in vivo IgE production.

Taken together, we demonstrated here that, in vitro, IL-17 could not directly induce Ig production by B cells and that Th17 cell-derived IL-17 was not required for it through T-B cell interaction. These observations suggest that, in vivo, IL-17 may be indirectly involved in Ig production by enhancing production of B-cell activator(s) by other immune cells. 


\section{Acknowledgments}

This work was supported by grants from the Ministry of Education, Culture, Sports, Science and Technology, Japan, Grants-in-Aid for Young Scientists (B) (A.S., E.S. A.N. and S.N), a Grant-in-Aid for Scientific Research on Priority Areas (S.S.) and the Program for Improvement of Research Environments for Young Researchers, The Special Coordination Funds for Promoting Science and Technology (S.N.), and by grants from Japan Science and Technology Agency, PRESTO (S.N.).

\section{References}

[1] Paul WE. Pleiotropy and redundancy: T cell-derived lymphokines in the immune response. Cell. 1989;57:521-4.

[2] Snapper CM, Paul WE. Interferon-gamma and B cell stimulatory factor-1 reciprocally regulate Ig isotype production. Science. 1987;236:944-7.

[3] Bacharier LB, Geha RS. Molecular mechanisms of IgE regulation. J Allergy Clin Immunol. 2000;105:S547-58.

[4] Coffman RL, Lebman DA, Shrader B. Transforming growth factor beta specifically enhances IgA production by lipopolysaccharide-stimulated murine B lymphocytes. J Exp Med. 1989;170:1039-44.

[5] McIntyre TM, Klinman DR, Rothman P, Lugo M, Dasch JR, Mond JJ, et al. Transforming growth factor beta 1 selectivity stimulates immunoglobulin G2b secretion by lipopolysaccharide-activated murine B cells. J Exp Med. 1993;177:1031-7.

[6] Iwakura Y, Ishigame H, Saijo S, Nakae S. Functional specialization of interleukin-17 family members. Immunity. 2011;34:149-62.

[7] Nakae S, Komiyama Y, Nambu A, Sudo K, Iwase M, Homma I, et al. Antigen-specific $\mathrm{T}$ cell sensitization is impaired in IL-17-deficient mice, causing suppression of allergic cellular and humoral responses. Immunity. 2002;17:375-87.

[8] Nakae S, Nambu A, Sudo K, Iwakura Y. Suppression of immune induction of collagen-induced arthritis in IL-17-deficient mice. J Immunol. 2003;171:6173-7. 
[9] Doreau A, Belot A, Bastid J, Riche B, Trescol-Biemont MC, Ranchin B, et al. Interleukin 17 acts in synergy with B cell-activating factor to influence B cell biology and the pathophysiology of systemic lupus erythematosus. Nat Immunol. 2009;10:778-85.

[10] Hsu HC, Yang P, Wang J, Wu Q, Myers R, Chen J, et al. Interleukin 17-producing T helper cells and interleukin 17 orchestrate autoreactive germinal center development in autoimmune BXD2 mice. Nat Immunol. 2008;9:166-75.

[11] Mitsdoerffer M, Lee Y, Jager A, Kim HJ, Korn T, Kolls JK, et al. Proinflammatory T helper type 17 cells are effective B-cell helpers. Proc Natl Acad Sci U S A. 2010;107:14292-7.

[12] Ozaki K, Spolski R, Feng CG, Qi CF, Cheng J, Sher A, et al. A critical role for IL-21 in regulating immunoglobulin production. Science. 2002;298:1630-4.

[13] Nakae S, Suto H, Berry GJ, Galli SJ. Mast cell-derived TNF can promote Th17 cell-dependent neutrophil recruitment in ovalbumin-challenged OTII mice. Blood. 2007;109:3640-8.

[14] Nurieva RI, Chung Y, Hwang D, Yang XO, Kang HS, Ma L, et al. Generation of T follicular helper cells is mediated by interleukin-21 but independent of T helper 1, 2, or 17 cell lineages. Immunity. 2008;29:138-49.

[15] Ishigame H, Kakuta S, Nagai T, Kadoki M, Nambu A, Komiyama Y, et al. Differential roles of interleukin-17A and $-17 \mathrm{~F}$ in host defense against mucoepithelial bacterial infection and allergic responses. Immunity. 2009;30:108-19.

[16] Yang XO, Chang SH, Park H, Nurieva R, Shah B, Acero L, et al. Regulation of inflammatory responses by IL-17F. J Exp Med. 2008;205:1063-75.

[17] Milovanovic M, Drozdenko G, Weise C, Babina M, Worm M. Interleukin-17A promotes IgE production in human B cells. J Invest Dermatol. 2010;130:2621-8.

[18] Minegishi Y, Saito M, Tsuchiya S, Tsuge I, Takada H, Hara T, et al. Dominant-negative mutations in the DNA-binding domain of STAT3 cause hyper-IgE syndrome. Nature. 2007;448:1058-62.

[19] Milner JD, Brenchley JM, Laurence A, Freeman AF, Hill BJ, Elias KM, et al. Impaired $\mathrm{T}(\mathrm{H}) 17$ cell differentiation in subjects with autosomal dominant hyper-IgE syndrome. Nature. 2008;452:773-6. 


\section{Figure legends}

Figure 1. Proportion of $\mathrm{PNA}^{+}$Fas $^{+} \mathrm{B}$ cells.

Single-cell suspensions were prepared from wild-type (WT) and IL-17 ${ }^{-/-}$mice after immunization with OVA emulsified with alum. The proportion of $\mathrm{PNA}^{+} \mathrm{Fas}^{+}$cells in 7-aminoactinomycin D-negative $\mathrm{B} 220^{+}$cells was determined by flow cytometry. (A) Representative FACS results are shown. (B) The data show the mean + SEM. Open columns show WT mice $(n=3)$, and closed columns show $\mathrm{IL}^{-17^{-/-}}$mice $(\mathrm{n}=3)$.

\section{Figure 2. Expression of IL-17RA and IL-17RC in primary splenic B cells.}

IL-17RA and IL-17RC mRNA expression in splenic B cells purified from wild-type mice was determined by RT-PCR analysis. B: primary splenic B cells; C: control cDNA templates; and - : no templates.

\section{Figure 3. Effect of IL-17 on B-cell Ig production.}

Splenic B cells $\left(2 \times 10^{6}\right.$ cells $\left./ \mathrm{ml}\right)$ were stimulated with various concentrations of IL-17 in the presence and absence of anti-CD40 mAb for 6 days. The levels of $\operatorname{IgA}, \operatorname{IgE}, \operatorname{IgG} 1$, IgG2a, IgG2b, IgG2c and IgG3 in the culture supernatants were measured by ELISA. Data show the mean $\pm \operatorname{SEM}(\mathrm{n}=6) .{ }^{*} \mathrm{p}<0.05, * * \mathrm{p}<0.01$ vs. (-) (without anti-CD40 mAb); and ${ }^{\dagger} \mathrm{p}=0.05,{ }^{\dagger \dagger} \mathrm{p}<0.01$ vs. IL-17 $=0 \mathrm{ng} / \mathrm{ml}$ (with anti-CD40). Similar results were obtained in four independent experiments. The dashed line is the threshold for the limit of detection by ELISA. 
Figure 4. Effects of IL-17 on IFN- $\gamma$-, IL-4- and TGF- $\beta 1$-mediated Ig class-switching. Splenic B cells were stimulated with various concentrations of IL-17 in the presence of IFN- $\gamma \quad$ IL-4 or TGF- $\beta 1$, with and without anti-CD40 mAb for 6 days. The levels of $\operatorname{IgA}, \operatorname{IgE}, \operatorname{IgG} 1, \operatorname{IgG} 2 \mathrm{a}, \operatorname{IgG} 2 \mathrm{~b}$ and $\operatorname{IgG} 3$ in the culture supernatants were measured by ELISA. Data show the mean $\pm \operatorname{SEM}(n=6) . * p<0.05, * * p<0.01$ vs. (-) (without anti-CD40 mAb) and ${ }^{\dagger} \mathrm{p}=0.05$ vs. IL-17 $=0 \mathrm{ng} / \mathrm{ml}$ (with anti-CD40 mAb). Similar results were obtained in two independent experiments. The dashed line is the threshold for the limit of detection by ELISA.

Figure 5. T-cell-derived IL-17 is not essential for Ig production by B cells.

Splenic B cells were co-cultured with purified $\mathrm{CD} 4^{+} \mathrm{T}$ cells from OTII or IL-17 ${ }^{-/-}$OTII mice in the presence and absence of $\mathrm{OVA}_{323-339}$ peptides (OVAp) for 6 days. The levels of IgA, IgE, IgG1, IgG2b, IgG2c and IgG3 in the culture supernatants were measured by ELISA. Data show the mean $\pm \operatorname{SEM}(n=10) .{ }^{*} \mathrm{p}<0.05,{ }^{*} \mathrm{p}<0.01$ vs. Medium. Similar results were obtained in two independent experiments.

Figure 6. Th17-cell-derived IL-17 is not essential for Ig production by B cells.

Splenic B cells were co-cultured with in vitro skewed Th17 cells derived from OTII ( $\mathrm{n}=$

12) or IL-17 ${ }^{-/}$OTII $(n=9)$ mice in the presence and absence of $\mathrm{OVA}_{323-339}$ peptides for 6 days. The levels of IgA, IgE, IgG1, IgG2b, IgG2c, IgG3 and IL-17 in the culture supernatants were measured by ELISA. Data show the mean \pm SEM. ${ }^{*} \mathrm{p}<0.05, * * \mathrm{p}<0.01$ 
vs. Medium; and ${ }^{\dagger \dagger} \mathrm{p}<0.01$ vs. WT OTII Th17 cells. Similar results were obtained in two independent experiments.

\section{Figure 7. Effect of IL-25 and IL-17F on B-cell Ig production.}

Splenic B cells $\left(2 \times 10^{6}\right.$ cells $\left./ \mathrm{ml}\right)$ were stimulated with $100 \mathrm{ng} / \mathrm{ml}$ of $\mathrm{rmIL}-17, \mathrm{rmIL}-17 \mathrm{~F}$ or rmIL-25 in the presence and absence of anti-CD40 mAb for 6 days. The levels of IgA, IgE, IgG1, IgG2a, IgG2b, IgG2c and IgG3 in the culture supernatants were measured by ELISA. Data show the mean \pm SEM $(n=6) . * p<0.05, * * p<0.01$ vs. (-) (without anti-CD40 mAb).

\section{Figure 8. Effect of Th17 cell-derived IL-21 on B-cell Ig production}

Splenic B cells from wild-type $(n=3)$ and IL-21R $R^{-/-}(n=3$ to 4$)$ mice were co-cultured with in vitro skewed Th17 cells derived from OTII mice in the presence and absence of OVA $_{323-339}$ peptides for 6 days. The levels of IgA, IgE, IgG1, IgG2b, IgG2c and IgG3 in the culture supernatants were measured by ELISA. Data show the mean $\pm \mathrm{SEM}$. ${ }^{*} \mathrm{p}<0.05$, ${ }^{* *} \mathrm{p}<0.01$ vs. Medium; and ${ }^{\dagger} \mathrm{p}<0.05,{ }^{\dagger \dagger} \mathrm{p}<0.01$ vs. wild-type B cells. 
Figures

Shibui et al. Figure 1

A
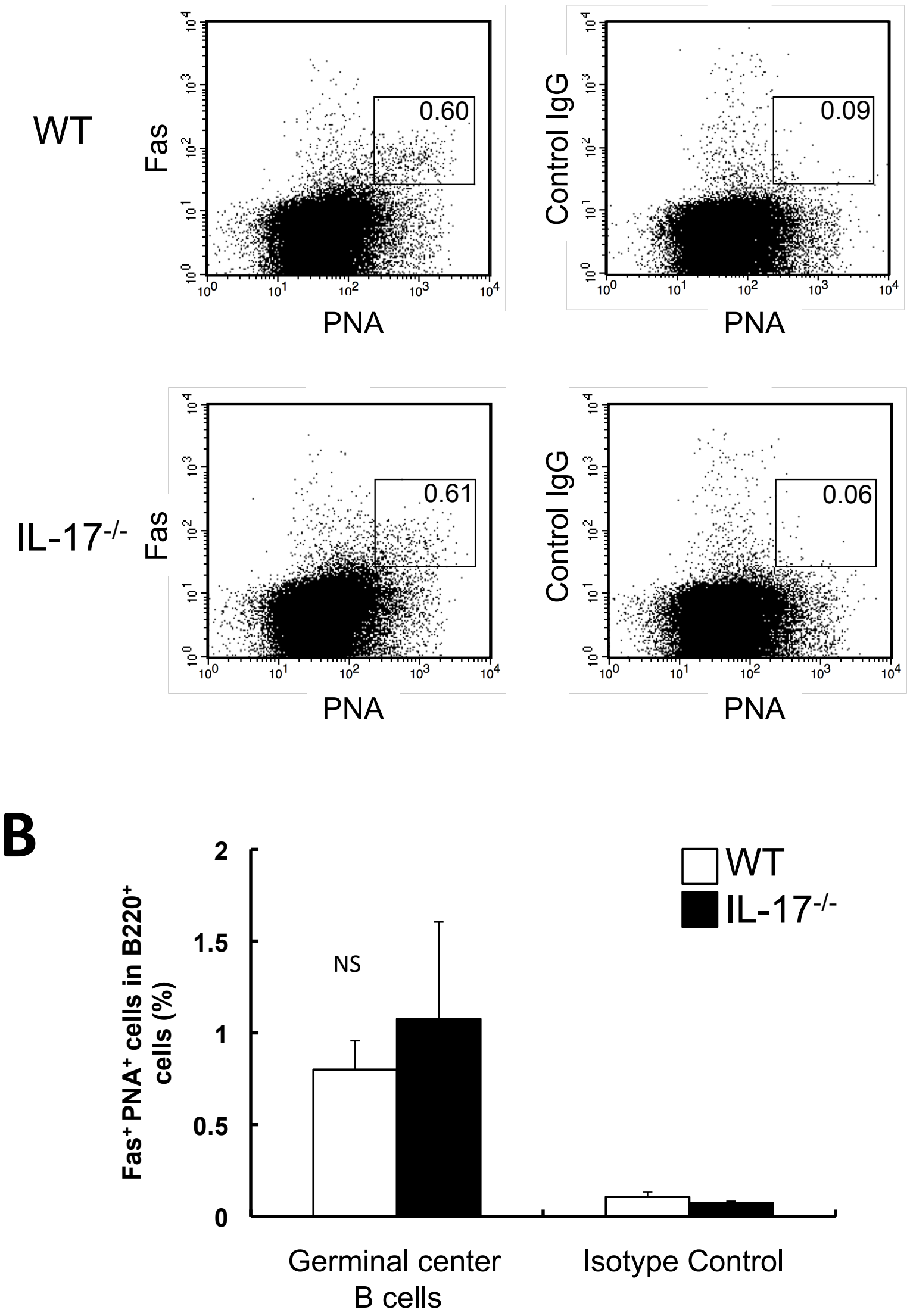
Shibui et al. Figure 2

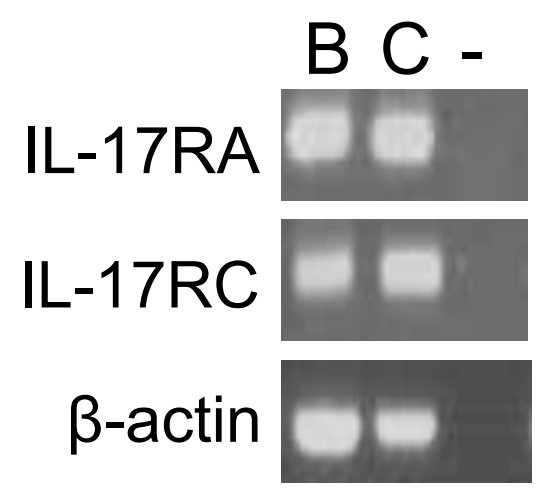




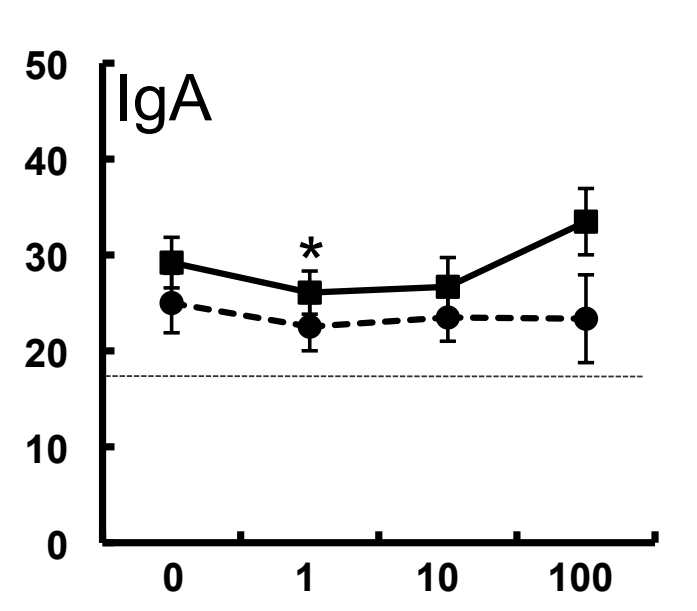

Shibui et al. Figure 3
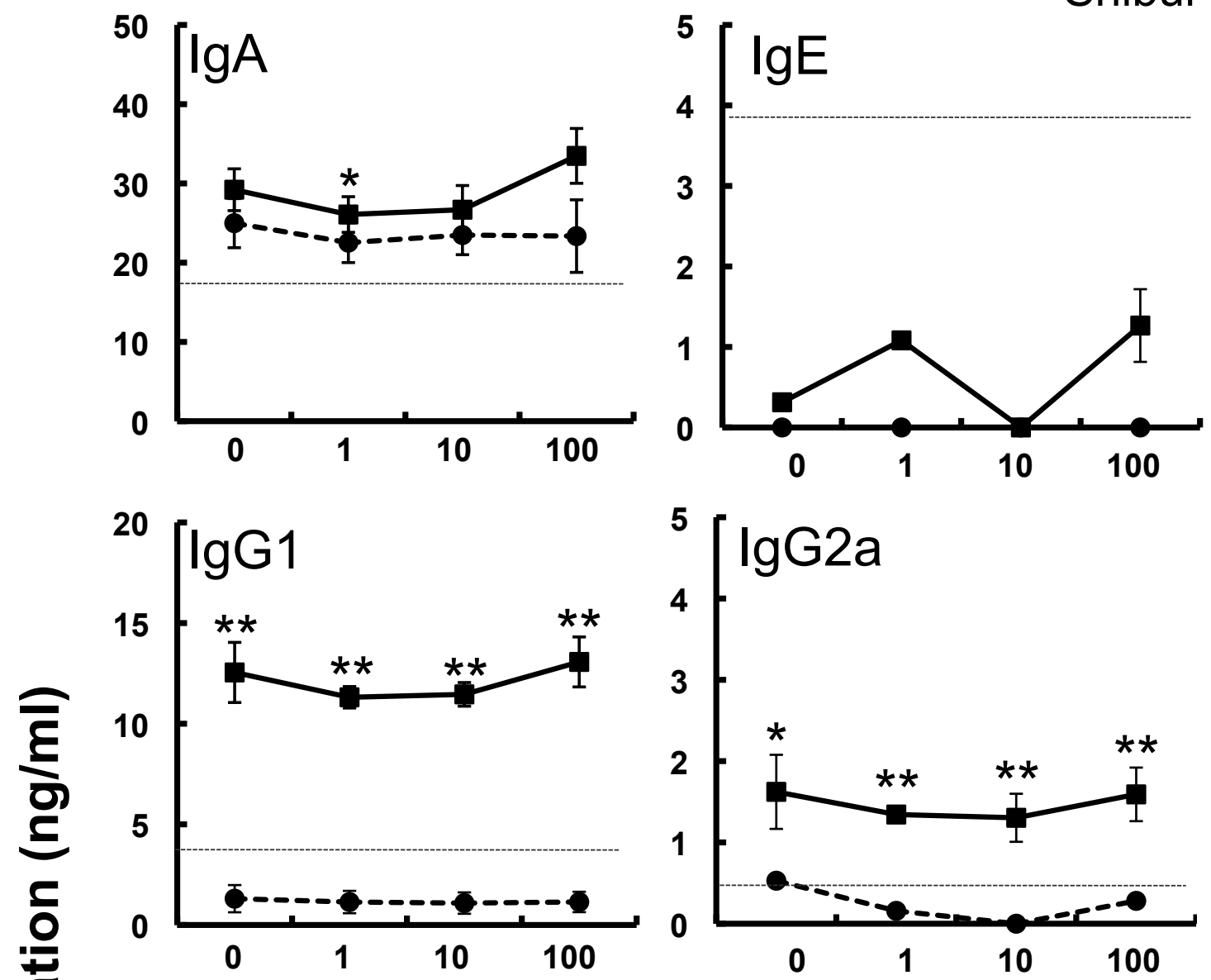

동
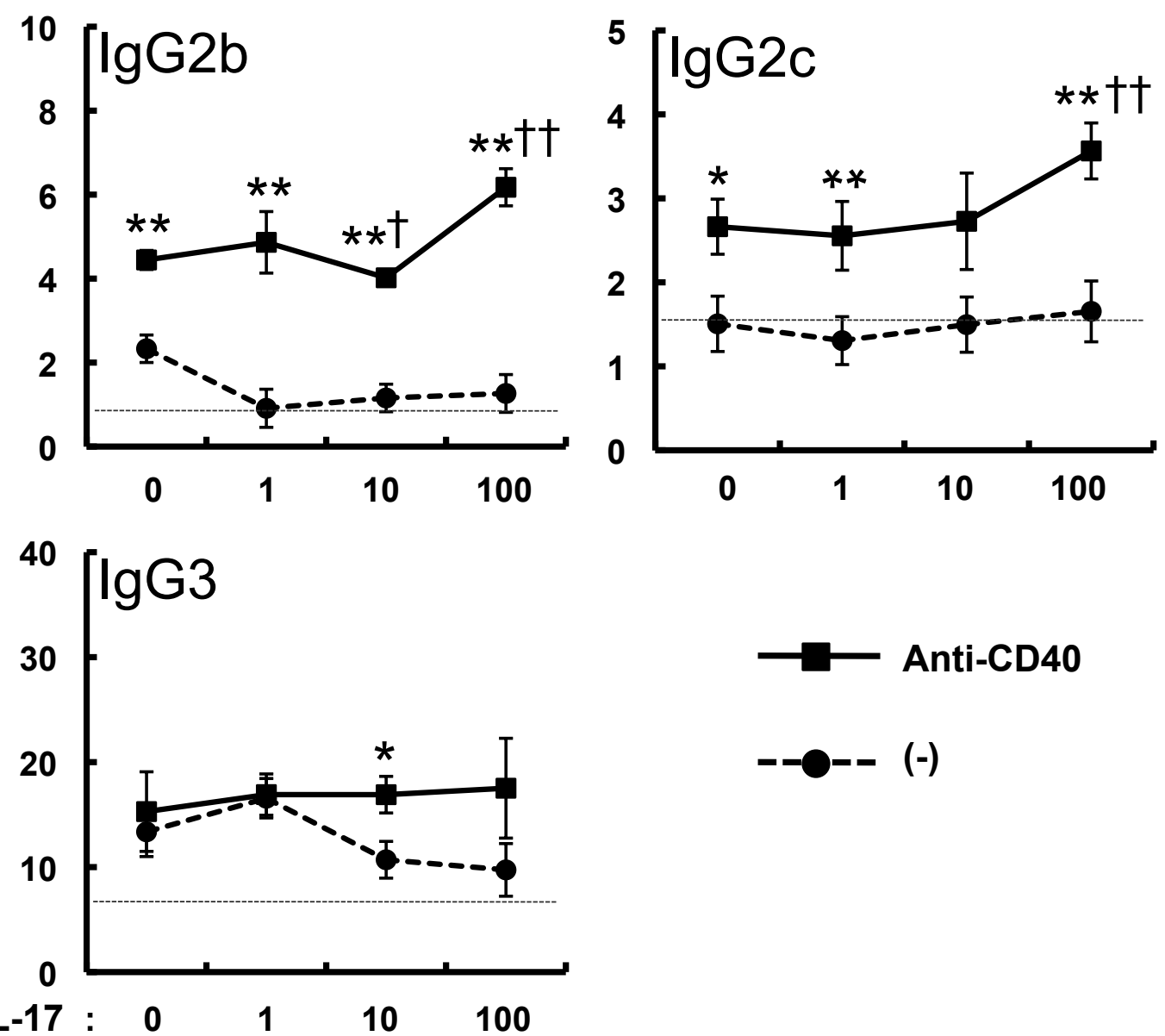

(ng/ml) 
Shibui et al. Figure 4
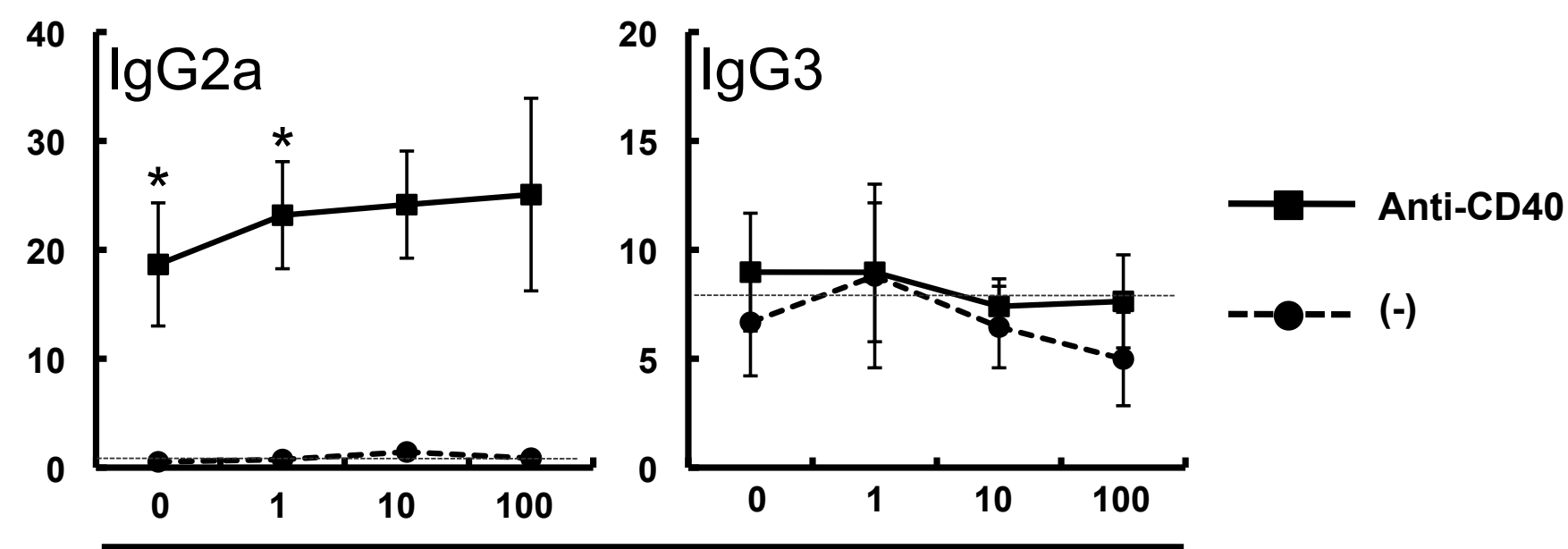

+ IFN-Y
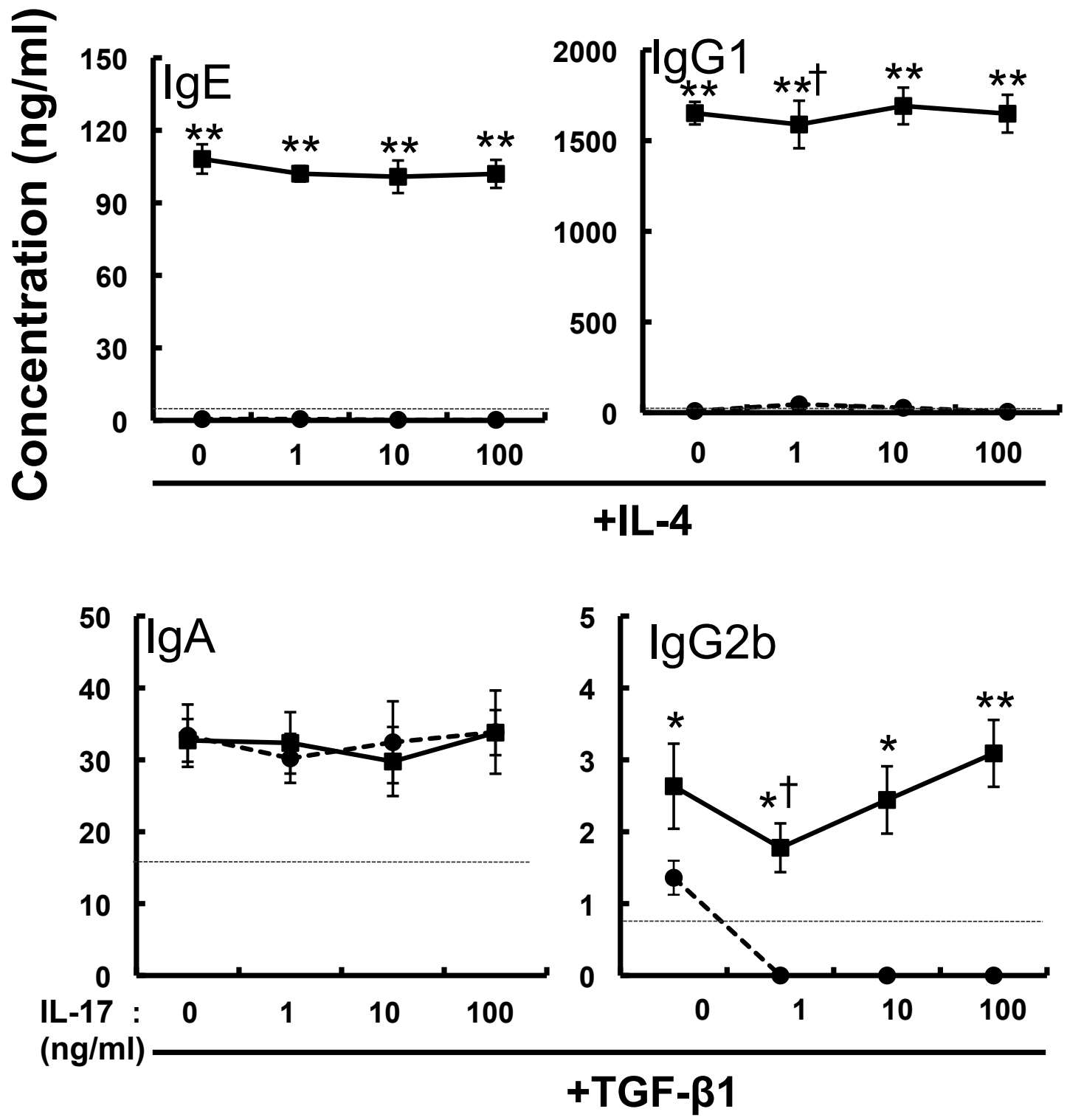
Shibui et al. Figure 5
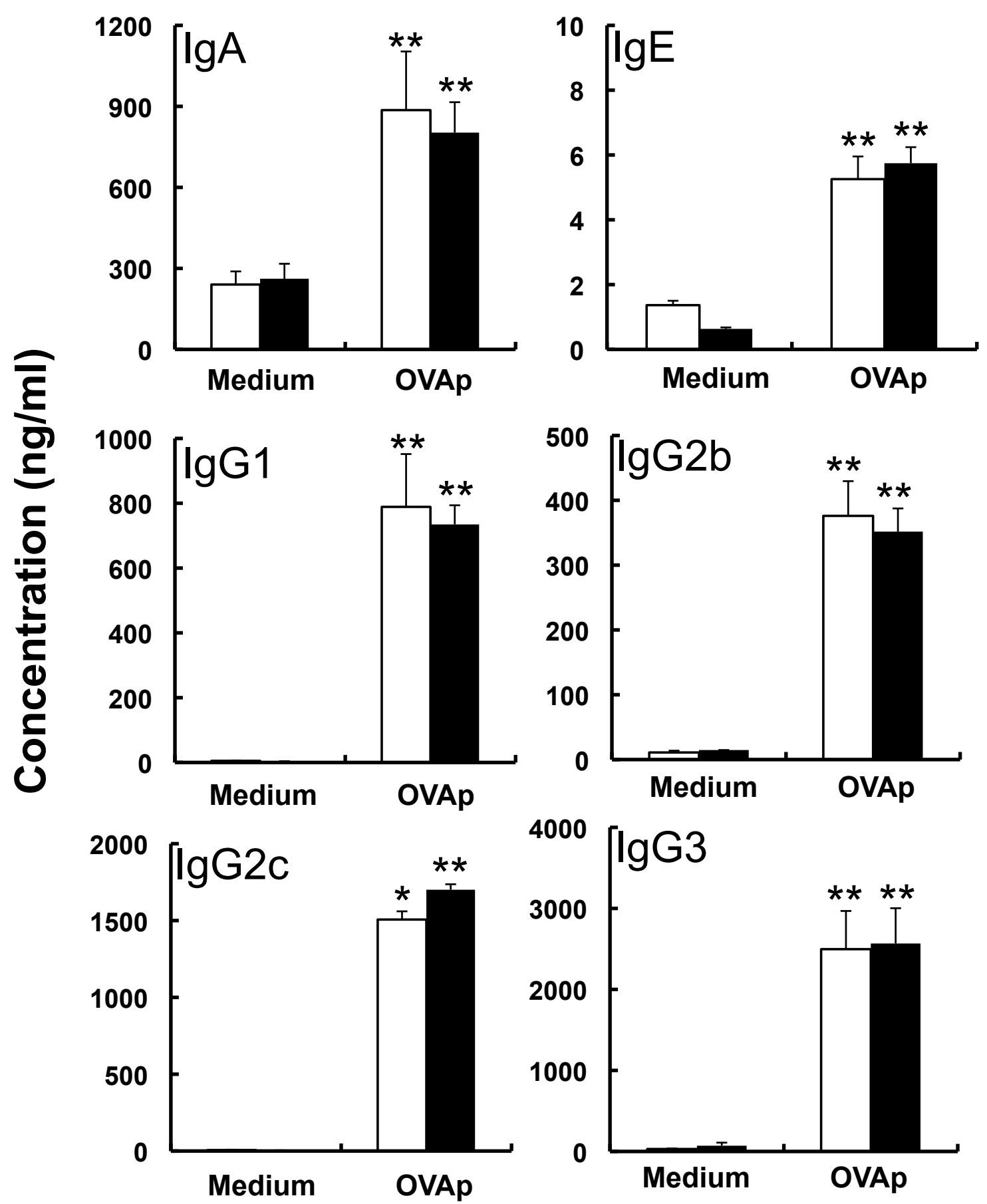

WT B cells +

$\square$ WT OTII T cells

IL-17-/- OTII T cells 
Shibui et al. Figure 6

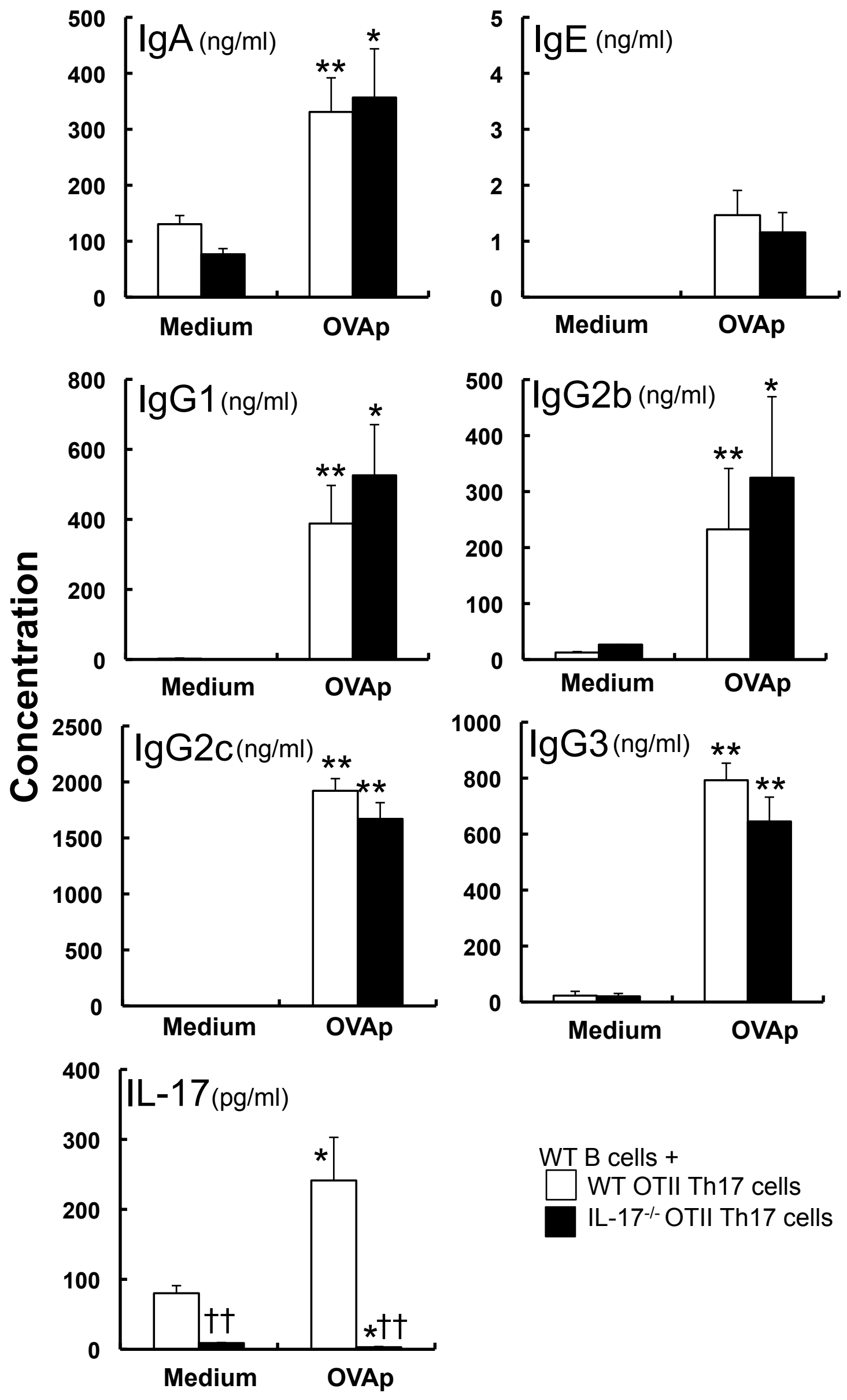


Shibui et al. Figure 7
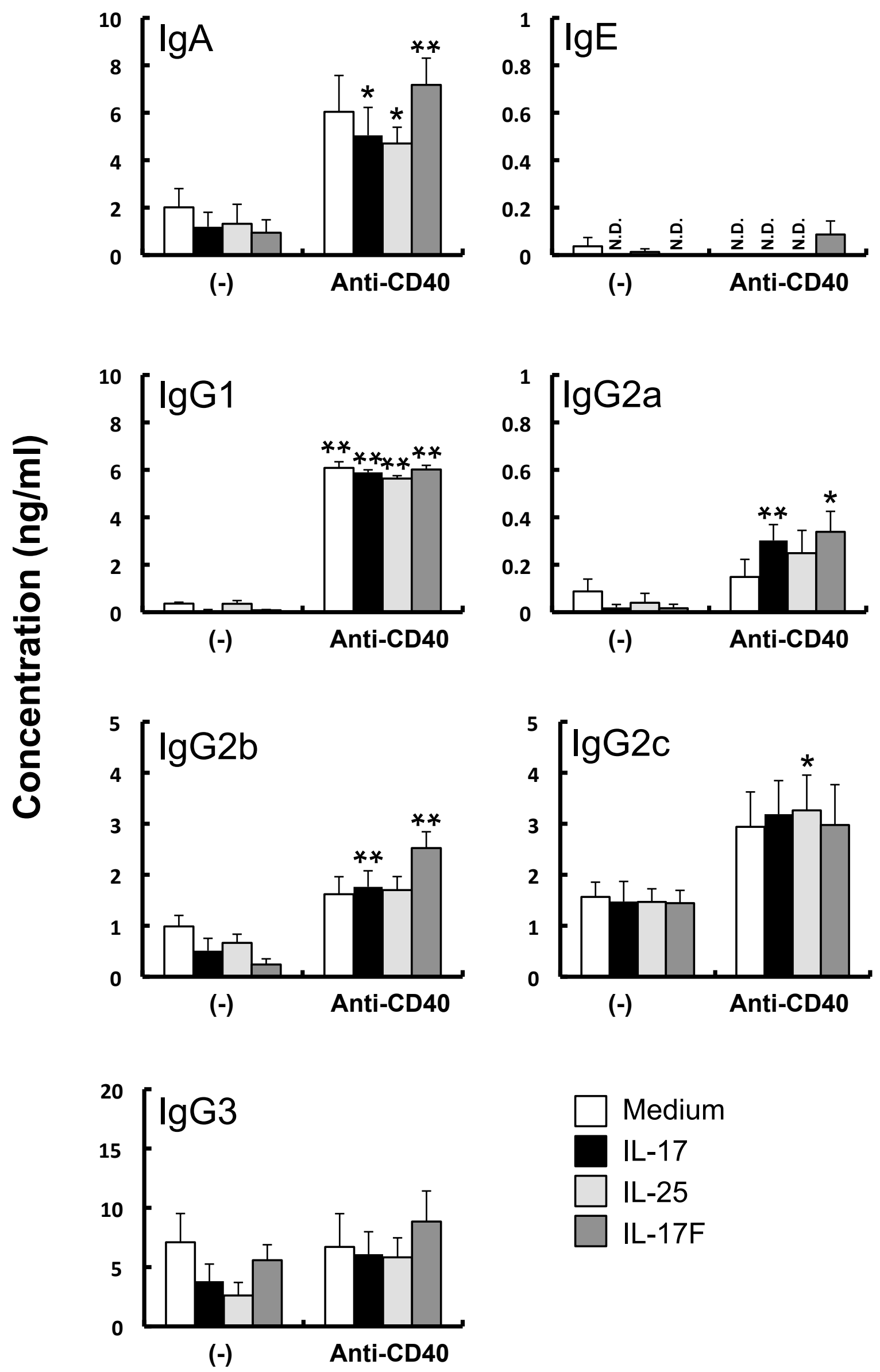
Shibui et al. Figure 8
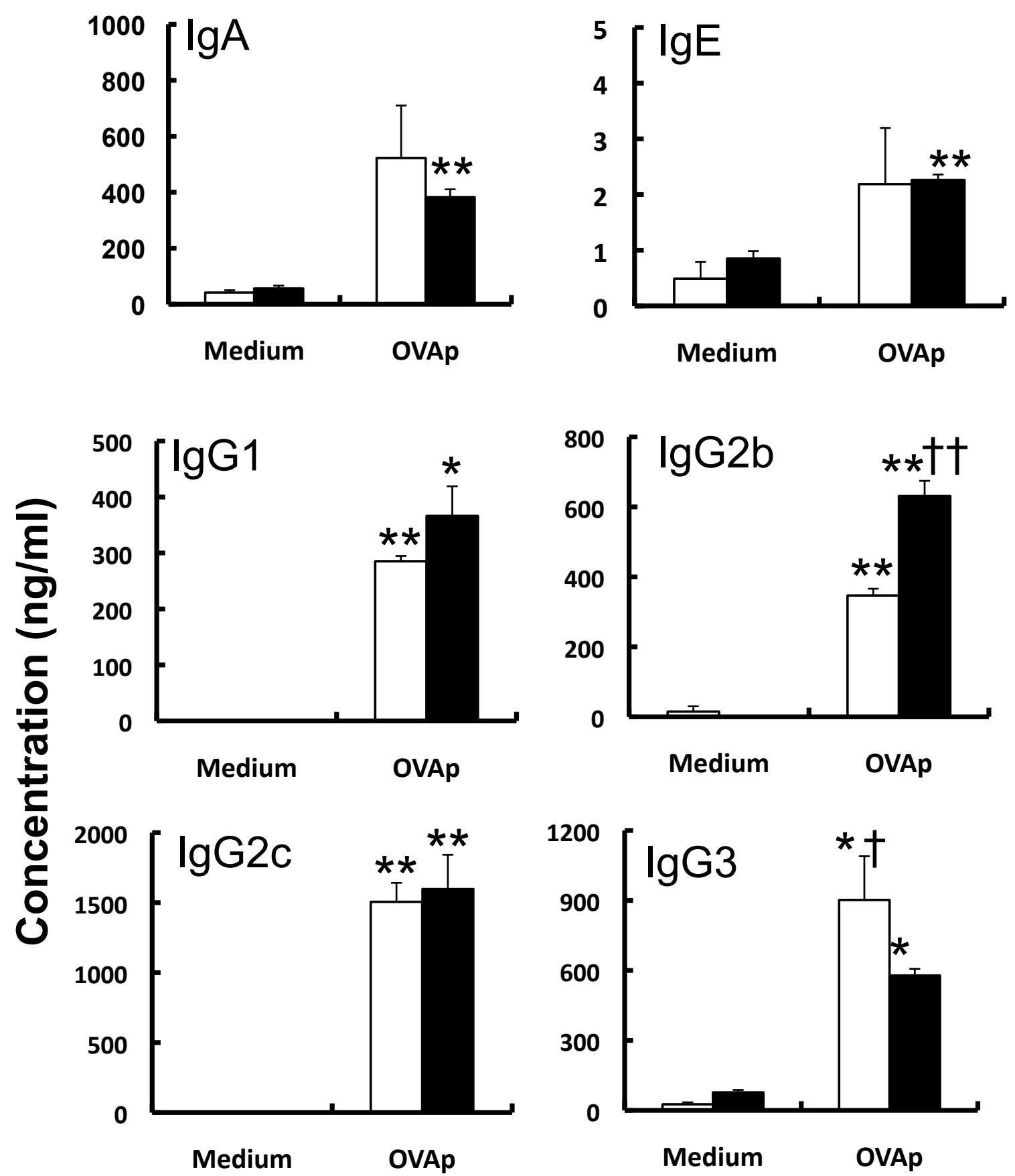

OT-II Th17 cells +

$\square$ WT B cells

IL-21R ${ }^{-/-} B$ cells 